\title{
Allelopathic effects of Baltic Sea spring bloom dinoflagellates on co-occurring phytoplankton
}

\author{
Sanna Suikkanen*, Päivi Hakanen, Kristian Spilling, Anke Kremp
}

Finnish Environment Institute, Marine Research Centre, 00251 Helsinki, Finland

\begin{abstract}
Dinoflagellate-dominated spring blooms are globally uncommon, but they regularly occur and are even increasing in the Baltic Sea, varying interannually in importance with diatomdominated blooms. The success of dinoflagellates in the spring phytoplankton community has remained poorly understood, as they are expected to be inferior competitors due to their low growth rates and nutrient uptake capacities under nutrient-replete spring conditions. To prevail in the phytoplankton community, dinoflagellates must either be favored by specific environmental settings or possess adaptations, such as allelopathy, to compensate for their competitive disadvantage. Using batch cultures, we studied the allelopathic effects of 3 dominant vernal dinoflagellates-Biecheleria baltica, Gymnodinium corollarium and Scrippsiella hangoei-on 5 typical spring bloom diatoms and 1 cryptophyte. We also tested the effects of the dinoflagellates on each other. Three of the 5 diatoms - Melosira arctica, Skeletonema marinoi and Thalassiosira balticawere significantly inhibited by cell-free filtrates or live cells of all dinoflagellates. Chaetoceros cf. wighamii and Diatoma tenuis were suppressed by G. corollarium, and D. tenuis was also suppressed by live cells of $S$. hangoei. In contrast, the cryptophyte Rhodomonas sp. was stimulated by all dinoflagellate species. The effects of dinoflagellate filtrates on other dinoflagellate species were mostly positive, but co-culturing tended to inhibit the growth of the respective target dinoflagellates. As some of the major players of the diatom spring bloom can be suppressed by cooccurring dinoflagellates in culture, we conclude that allelopathy may be one mechanism by which vernal dinoflagellates frequently outcompete diatoms and form intense spring blooms.
\end{abstract}

KEY WORDS: Allelopathy · Baltic Sea $\cdot$ Spring bloom $\cdot$ Dinoflagellate $\cdot$ Biecheleria baltica Gymnodinium corollarium $\cdot$ Scrippsiella hangoei $\cdot$ Diatom

\section{INTRODUCTION}

In contrast to most temperate coastal ecosystems where diatoms form the main part of phytoplankton spring blooms, vernal phytoplankton communities in the Baltic Sea are characterized by co-occurrence, and often dominance, of cold-water dinoflagellates. There is high interannual variability in the Baltic spring blooms with diatoms and dinoflagellates alternating in dominance (cf. Kremp et al. 2008 and our Fig. 1). Typically the blooms start immediately after ice break-up in March/early April and last for up to
2 mo (Heiskanen 1993, Kremp \& Heiskanen 1999). Due to their similar size and shape, the taxonomic affiliations of the Baltic spring bloom dinoflagellate species have long been unclear. Recent morphological and molecular analyses on cultured isolates revealed that 3 different species, inseparable by light microscopy, are associated with these blooms (Larsen et al. 1995, Kremp et al. 2005, Sundström et al. 2009). It was established that Biecheleria baltica Moestrup, Lindberg et Daugbjerg (= Woloszynskia halophila sensu Kremp et al. 2005) (Moestrup et al. 2009), cooccurs with Scrippsiella hangoei (Schiller) Larsen in 

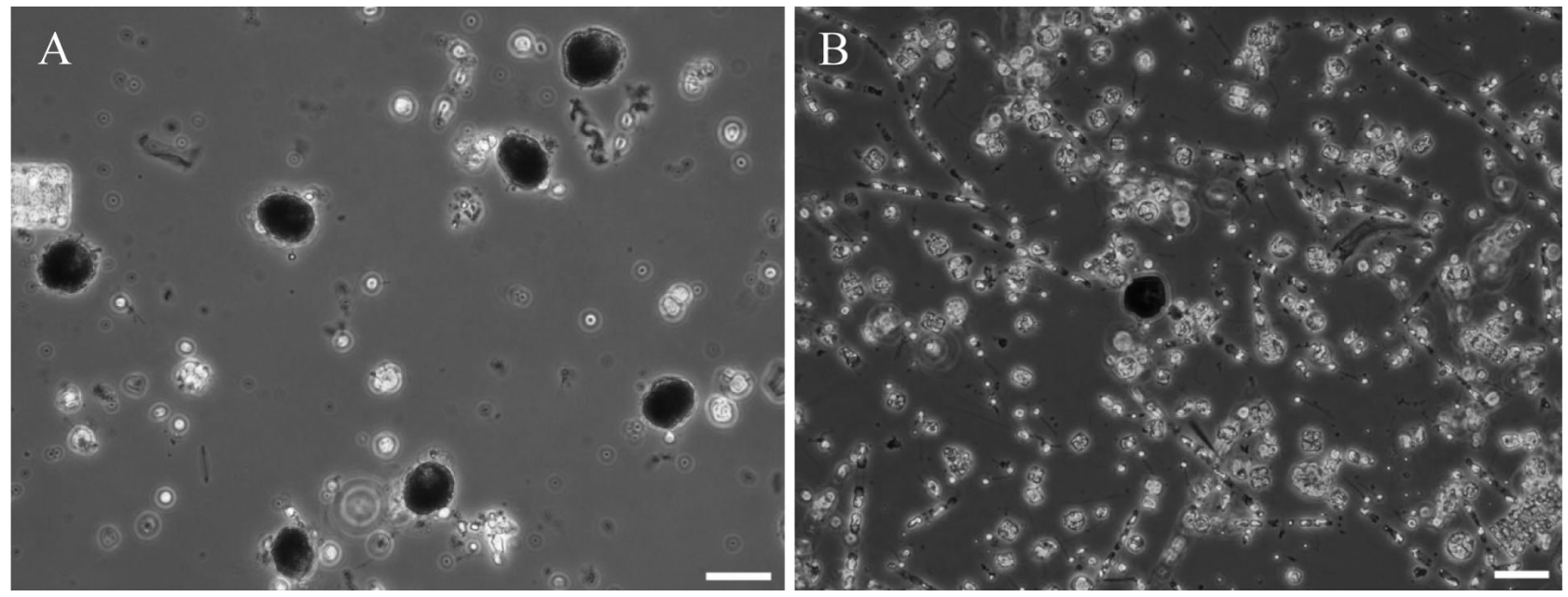

Fig. 1. Micrographs of 2 spring bloom communities in the northern Baltic Sea, dominated by (A) the dinoflagellate Biecheleria baltica in 2006, and (B) the diatom Skeletonema marinoi in 2008. Scale bars $=20 \mu \mathrm{m}$

the Gulf of Finland (Kremp et al. 2005), whereas a third recently described species, Gymnodinium corollarium A. M. Sundström, Kremp et Daugbjerg (Sundström et al. 2009), is most abundant in the Gulf of Bothnia and the open Baltic Proper. Other species typically belonging to the Baltic spring bloom community include the dinoflagellate Peridiniella catenata (Levander) Balech, and the diatoms Chaetoceros spp. Ehrenberg, Melosira arctica (Ehrenberg) Dickie, Skeletonema marinoi Sarno et Zingone, Thalassiosira baltica (Grunow) Ostenfeld, T. levanderi van Goor and Achnanthes taeniata Grunow (Niemi 1975, Hällfors 2004).

In some areas of the Baltic Sea, dinoflagellates have become increasingly dominant relative to diatoms in spring blooms during the last decades (Wasmund et al. 1998, Wasmund \& Uhlig 2003, Klais et al. 2011). A concomitant decrease in terrestrial silicate discharges and an increase in other nutrients have been considered as a possible cause of such development, as they might lead to a deteriorating competitive position of co-occurring diatoms (Rahm et al. 1996). On the other hand, local physical conditions (e.g. mild winters, calm spring conditions) resulting from large-scale weather patterns, have been suggested to be more important than nutrients in explaining the shift towards dinoflagellate dominance (Wasmund et al. 1998, Klais et al. 2011).

Dinoflagellate-dominated spring blooms are considered a paradox, since dinoflagellates are regarded as inferior competitors relative to diatoms at high nutrient concentrations typical of spring in temperate areas. To counteract low nutrient uptake affinities com- pared with diatoms, other adaptive competitive strategies, such as motility, mixotrophy, allelopathy and antipredation defense mechanisms, have evolved in dinoflagellates (Smayda 1997). Allelopathy, i.e. the production and release of compounds that inhibit competitors, has been hypothesized to be an important competitive strategy of dinoflagellates under eutrophic conditions (Maestrini \& Bonin 1981, Smayda 1997). Particularly, bloom-forming dinoflagellates seem to use allelopathy as a mechanism to outcompete sympatric phytoplankters (Rengefors \& Legrand 2001) and to maintain their dense and nearly monospecific populations, many of which are toxic for a wide variety of organisms (Kubanek et al. 2005). Allelopathic properties have been reported from a number of dinoflagellate genera, including Prorocentrum spp., Cochlodinium spp., Karenia spp., Karlodinium spp., Peridinium spp. and Alexandrium spp. (Gentien \& Arzul 1990, Windust et al. 1996, Wu et al. 1998, Arzul et al. 1999, Adolf et al. 2006, Tang \& Gobler 2010). Additionally, lethal effects on other phytoplankton by direct cell contact have been detected in the genus Heterocapsa (Uchida et al. 1995).

Little is known of the mechanisms that allow the Baltic Sea spring dinoflagellates, which can be classified as red-tide organisms, to maintain their advantage, given the apparently superior competitive ability of co-occurring diatoms. Results from recent mesocosm experiments with natural spring phytoplankton indicated that initial dominance may be an important prerequisite for the later formation of dinoflagellate blooms: when dinoflagellates are established at high densities before the diatoms, such an 
outcome of competition appears to be independent of nutrient or light conditions (Kremp et al. 2008). This suggests that a competitive strategy which is particularly effective at high densities is used by these dinoflagellates to control competitors and keep their abundances low.

Allelopathy could be a competitive adaptation that explains the success of dinoflagellates in building up populations that frequently dominate the phytoplankton spring community in the Baltic Sea, by allowing dinoflagellates to suppress their competitors once high-density populations are established. We investigated whether the 3 most important vernal dinoflagellate species in the Baltic Sea - Biecheleria baltica, Gymnodinium corollarium and Scrippsiella hangoei-are able to inhibit their competitors, and whether allelopathy can thus provide a way to support their dominance. We hypothesized that (1) $B$. baltica, G. corollarium and $S$. hangoei would produce allelochemicals that inhibit the growth of co-occurring diatom species, and (2) these effects would be enhanced at high cell densities.

\section{MATERIALS AND METHODS}

\section{Algal cultures}

For the cross-culture experiments, we selected $9 \mathrm{im}$ portant species belonging to the phytoplankton community that annually constitutes the main part of the spring bloom biomass in the northern Baltic Sea (Niemi 1975, Fig. 1). As donors we used 3 cold-water dinoflagellates: Gymnodinium corollarium (strain GCTVB4, isolated from a bloom sample in the Northern Baltic Proper in May 2005), Biecheleria baltica and Scrippsiella hangoei (WHTVC1 and SHTV5, respectively, isolated from germinated resting cysts collected at the SW coast of Finland in March 2002). Target species included 1 cryptophyte, Rhodomonas sp. Karsten (Crypto07B1), and 5 diatoms, Chaetoceros cf. wighamii Brightwell (CWTVC1), Melosira arctica (MARTV), Skeletonema marinoi (SMATV), Thalassiosira baltica (TBTV) and Diatoma tenuis Agardh (DTTVB5). All diatoms were originally isolated from single cells at the SW coast of Finland in 2005. All strains are maintained at the Marine Research Centre, Finnish Environment Institute. In addition, we investigated the reciprocal effects of the 3 dinoflagellates.

All strains were grown in F/2 medium (Guillard 1975), prepared from GF/F filtered, autoclaved seawater (salinity 6 ), at $+4{ }^{\circ} \mathrm{C}$, in $150 \mu \mathrm{mol}$ photons $\mathrm{m}^{-2}$ $\mathrm{s}^{-1}$, and in a light:dark cycle of 12L:12D. The dinoflagellates were grown in F/2 medium without silicate addition. Before the start of the experiment, the donors had reached late exponential or stationary growth phase, whereas the targets were growing exponentially.

\section{Experimental design}

For the first set of experiments, we used one dense donor dinoflagellate concentration of ca. 10000 cells $\mathrm{ml}^{-1}$, which corresponds to bloom conditions in the field (e.g. Heiskanen 1993, Larsen et al. 1995, Jaanus et al. 2006, Spilling 2007). Starting concentrations of the target species were ca. 500 cells ml $^{-1}$ for the large (Melosira arctica, Thalassiosira baltica, Diatoma tenuis, Biecheleria baltica, Gymnodinium corollarium, Scrippsiella hangoei) and 1300 cells $\mathrm{ml}^{-1}$ for the small (Rhodomonas sp., Chaetoceros cf. wighamii, Skeletonema marinoi) species. The concentrations were chosen so that counting of $1 \mathrm{ml}$ samples produced statistically reliable results, and that the biovolumes of the different target species corresponded with each other. The effects of filtrates, as well as live cells of donor species, were compared to the control (described below, this subsection).

To check for linearity in the response, we conducted a second experiment where we compared the effects of 4 donor concentrations $(1,10,50$ and $100 \%$ of the starting concentration) on Skeletonema marinoi. The starting (100\%) concentrations of donor dinoflagellates were 11600 Scrippsiella hangoei cells $\mathrm{ml}^{-1}, 16300$ Gymnodinium corollarium cells $\mathrm{ml}^{-1}$ and 25900 Biecheleria baltica cells $\mathrm{ml}^{-1}$. Starting concentration of $S$. marinoi was ca. 3000 cells ml ${ }^{-1}$. In this experiment, the effects of donor filtrates were tested; live cells were applied only in the case of $B$. baltica.

All experiments were conducted using batch cultures of target cells. The treatments were culture filtrate and live cells of donor species, and F/2 medium was used as the control. The filtrate was prepared by gently filtering the donor culture through a Whatman GF/F filter, with a pressure of $<5 \mathrm{kPa}$ to avoid breaking the dinoflagellate cells. Nutrients were added to the filtrate and the live donor cells in $\mathrm{F} / 2$ concentrations. To reach the desired donor filtrate or cell concentrations and starting target cell numbers, the experimental cultures were diluted with $\mathrm{F} / 2$ medium.

The experiments were conducted at $+4{ }^{\circ} \mathrm{C}$, in $50 \mathrm{ml}$ tissue culture flasks, with an experimental volume of $40 \mathrm{ml}$ and triplicates of each treatment. To avoid 
settling of the diatoms, culture flasks were attached to a plankton wheel with a rolling velocity of $\sim 1 \mathrm{rpm}$ and variation in light intensity from 50 to $114 \mu \mathrm{mol}$ photons $\mathrm{m}^{-2} \mathrm{~s}^{-1}$. The Rhodomonas sp. and dinoflagellate cultures were grown without turbulence at $150 \mu \mathrm{mol}$ photons $\mathrm{m}^{-2} \mathrm{~s}^{-1}$. The light:dark cycle was 12L:12D for all target cultures.

To avoid effects of resource competition due to nutrient deficiency in the treatments with mixed donor and target cells, nutrients were added one or 2 times (once in 5 to $6 \mathrm{~d}$ ) during the experiments. The additions were made in F/2 concentrations, with the exception that twice the F/2 concentration of phosphate was added to the treatments with Scrippsiella hangoei cells, because of larger P consumption by this species (Kremp et al. 2009).

\section{Analyses}

Samples ( $\mathrm{V}=1.8 \mathrm{ml}$ ) were taken every 1 to $4 \mathrm{~d}$ for fluorescence measurement, and 3 times during the experiment for cell counts. Fluorescence was immediately measured using Varian Cary Eclipse Fluorescence Spectrophotometer (excitation 430 nm, emission $680 \mathrm{~nm}$ ) with a well-plate reader. Samples for cell counts were preserved with a drop of acid Lugol solution and counted using Sedgewick-Rafter cells ( $\mathrm{V}=1 \mathrm{ml}$ ) and an inverted microscope. A minimum of 400 counting units of each species were enumerated per sample, but if the total number was $<400$, all units were counted from the whole chamber area.

The experiments lasted from 11 to $14 \mathrm{~d}$ (with diatom and cryptophyte targets) to $18 \mathrm{~d}$ (dinoflagellate targets). On the last experimental day, the $\mathrm{pH}$ of the different treatments (filtrate and live cells) and the control was measured from 1 of the replicated flasks.

\section{Statistical analysis}

Repeated measures ANOVA was used to test for differences in cell numbers between the target cultures treated with filtrates or live cells of dinoflagellates and the control over the entire experimental period. Tukey's HSD post hoc test was used to find out which treatments significantly differed from the control and from each other. The data were tested for normality and homogeneity of variances. All tests were 2-tailed, with a significance level of $p=0.05$. If the treatments differed according to the ANOVA, only the Tukey HSD results are indicated. The statis- tical analysed were performed using the software SPSS 15.0.1 for Windows.

\section{RESULTS}

\section{Effects of dinoflagellates on diatom and cryptophyte growth}

In general, the dinoflagellate treatments exerted significant negative effects on the cell number development of the 5 diatom species; by contrast, their effects on the cryptophyte Rhodomonas sp. were mostly positive (Fig. 2). Live dinoflagellate cells usually had a stronger negative effect on the target species than cell-free filtrate. The most affected diatom species were Skeletonema marinoi, which was significantly inhibited by filtrates and live cells of Biecheleria baltica (Tukey HSD, $\mathrm{p}=0.021$ and $\mathrm{p}<0.001$, respectively) and Scrippsiella hangoei ( $\mathrm{p} \leq 0.001$ for both filtrate and live cells); Melosira arctica, which was decreased by live cells of B. baltica and Gymnodinium corollarium ( $\mathrm{p}<0.001$ for both), and both filtrates and live cells of $S$. hangoei ( $\mathrm{p} \leq 0.001$ for both); and Thalassiosira baltica, which was decreased by live cells, but not filtrates, of all 3 dinoflagellates $(\mathrm{p}<$ 0.001 for all).

Chaetoceros cf. wighamii was significantly decreased by live cells of Gymnodinium corollarium ( $\mathrm{p}=0.008)$, but increased by both filtrate and cells of Scrippsiella hangoei $(\mathrm{p}=0.037$ and $\mathrm{p}<0.001$, respectively). Diatoma tenuis was decreased by filtrate and live cells of $G$. corollarium ( $p=0.001$ for both) and cells of $S$. hangoei ( $\mathrm{p}=0.003)$, but increased by filtrate of Biecheleria baltica $(\mathrm{p}=0.001)$ and $S$. hangoei $(\mathrm{p}=0.012)$. Rhodomonas $\mathrm{sp}$. was significantly stimulated by all dinoflagellate treatments $(\mathrm{p} \leq 0.005$ for all), except for live $S$. hangoei cells, which had no significant effect on its cell numbers.

In the fluorescence data (not shown), similar responses were observed, except for the significant negative effects of Gymnodinium corollarium filtrate on the fluorescence of Chaetoceros cf. wighamii (repeated measures ANOVA, $\left.F_{1,4}=73.89, \mathrm{p}=0.001\right)$, Melosira arctica $\left(F_{1,4}=13.77, \mathrm{p}=0.021\right)$ and Skeletonema marinoi $\left(F_{1,4}=16.27, \mathrm{p}=0.016\right)$, and the significant positive effect of Biecheleria baltica filtrate on C. cf. wighamii $\left(F_{1,4}=17.85, \mathrm{p}=0.013\right)$. Effects of donors to target fluorescence could not be evaluated in mixed culture.

At the end of the experiment, the controls had an average $\mathrm{pH}$ of 8.60 , filtrates 8.61 and live cell treatments 8.77 (Table 1). 


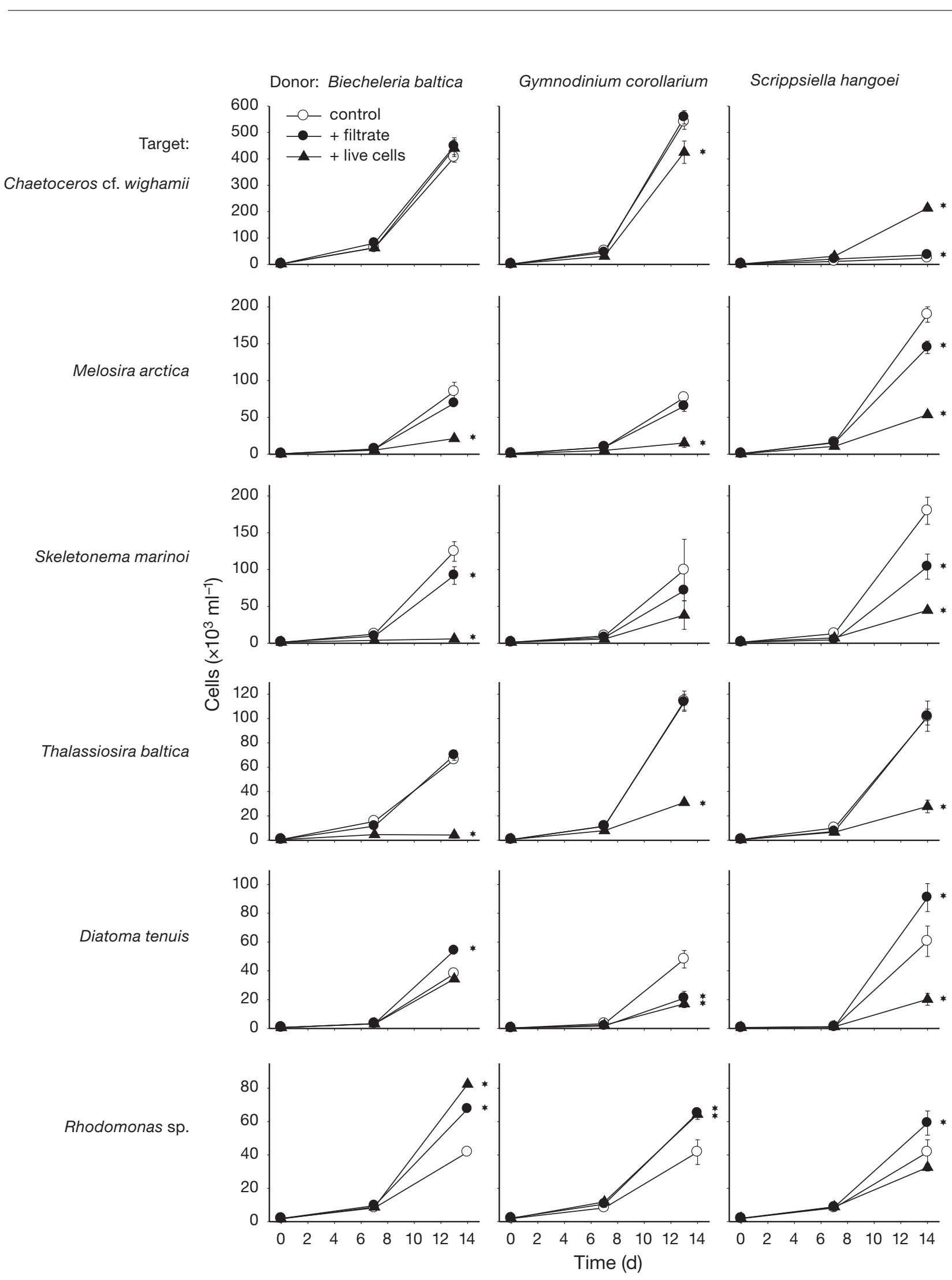

Fig. 2. Cell numbers $(n=3$, mean $\pm \mathrm{SD}$ ) of the 5 target diatoms and 1 cryptophyte, exposed to control medium, as well as cellfree filtrates and live cells of the 3 dinoflagellates Biecheleria baltica (left), Gymnodinium corollarium (middle) and Scrippsiella hangoei (right). Treatments in which the cell numbers significantly differ from the control $(\mathrm{p}<0.05)$ are marked with an asterisk 
Table 1. pH of the 5 target diatom, 1 cryptophyte, and 3 dinoflagellate cultures, exposed to control medium, as well as one concentration (corresponding to ca. 10000 cells ml $^{-1}$ ) of cell-free filtrates and live cells of Biecheleria baltica, Gymnodinium corollarium and Scrippsiella hangoei, on the first (start) and the last (end) day of the experiment

\begin{tabular}{|c|c|c|c|c|c|c|c|}
\hline & \multirow[t]{2}{*}{ Control } & \multicolumn{2}{|c|}{ - B. baltica - } & \multicolumn{2}{|c|}{-G. corollarium - } & \multicolumn{2}{|c|}{-S. hangoei- } \\
\hline & & Filtrate & Cells & Filtrate & Cells & Filtrate & Cells \\
\hline Start & 8.94 & 8.91 & 8.97 & 9.21 & 9.55 & 9.35 & 9.55 \\
\hline Chaetoceros cf. wighamii (end) & 9.01 & 9.94 & 9.75 & 9.16 & 8.95 & 8.09 & 9.65 \\
\hline Melosira arctica (end) & 8.27 & 8.39 & 8.05 & 7.47 & 8.28 & 9.18 & 9.20 \\
\hline Skeletonema marinoi (end) & 7.88 & 8.07 & 7.98 & 7.34 & 7.89 & 8.16 & 9.03 \\
\hline Thalassiosira baltica (end) & 9.09 & 9.29 & 8.15 & 8.67 & 8.48 & 9.41 & 9.37 \\
\hline Diatoma tenuis (end) & 8.20 & 8.61 & 8.69 & 7.22 & 8.23 & 9.24 & 9.62 \\
\hline Rhodomonas sp. (end) & 9.15 & 9.05 & 8.81 & 8.74 & 8.64 & 8.96 & 9.05 \\
\hline B. baltica (end) & 8.18 & & & 8.38 & 8.84 & 8.26 & 9.13 \\
\hline G. corollarium (end) & 8.87 & 8.87 & 8.29 & & & 8.94 & 9.08 \\
\hline S. hangoei (end) & 8.92 & 8.89 & 8.76 & 8.97 & 8.97 & & \\
\hline
\end{tabular}

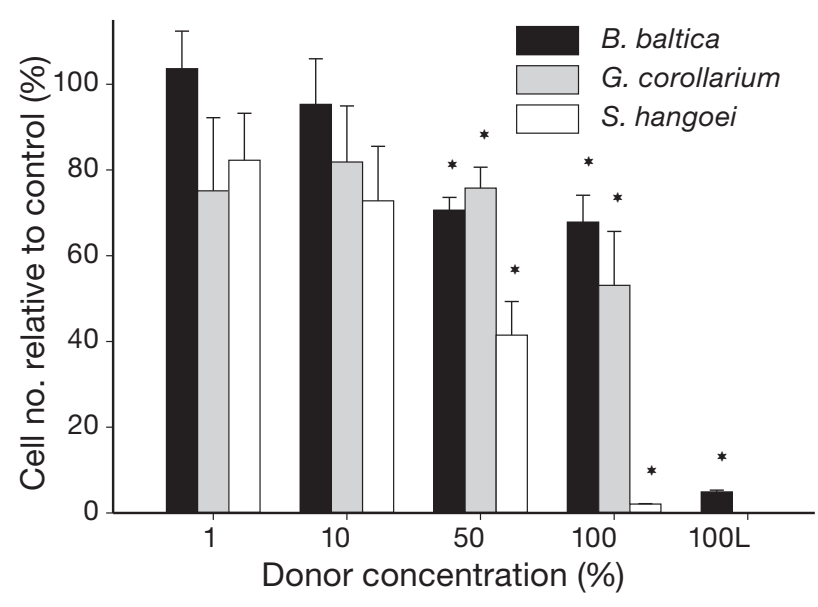

Fig. 3. Skeletonema marinoi. Cell number of the diatom relative to control $(\%)(n=3$, mean $\pm \mathrm{SD})$ on the last experimental day, exposed to 4 concentrations of cell-free filtrates of Biecheleria baltica, Gymnodinium corollarium and Scrippsiella hangoei. In addition to filtrates, live cells of $B$. baltica were applied (indicated by L). Treatments in which the cell numbers significantly differ from the control $(p<0.05)$ are marked with an asterisk

\section{Effects of varying filtrate concentrations on Skeletonema marinoi}

In the experiment where 4 different concentrations of dinoflagellate filtrates were added to Skeletonema marinoi cultures, the cell numbers of $S$. marinoi were negatively affected in the treatments with 50 and $100 \%$ concentrations of all 3 dinoflagellates (Fig. 3). The percentages corresponded with 13000 to 26000 Biecheleria baltica cells ml ${ }^{-1}$ (Tukey HSD, $\mathrm{p}=0.001$ and $<0.001$, respectively), 8000 to 16000 Gymnodinium corollarium cells $\mathrm{ml}^{-1}(\mathrm{p}=0.013$ and $<0.001)$, and 6000 to 12000 Scrippsiella hangoei cells ml ${ }^{-1}(\mathrm{p}<$ 0.001 for both). Fluorescence of $S$. marinoi was also significantly reduced by the $10 \%\left(1200 \mathrm{cells} \mathrm{m}^{-1}\right)$ $S$. hangoei filtrate $(\mathrm{p}=0.012)$. In addition, live B. baltica cells $\left(26000\right.$ cells ml ${ }^{-1}$ ) caused a significant $(\mathrm{p}<0.001)$ and much stronger decrease in $S$. marinoi cell numbers than the cell-free filtrate prepared from the same cell concentration. On the last day of the experiment, the 50 and $100 \%$ B. baltica filtrates had caused on average 29 and $32 \%$ decrease in S. marinoi cell numbers, respectively. In contrast, live $B$. baltica cells had decreased $S$. marinoi cell numbers by $95 \%$ by the same date. The 50 and $100 \%$ G. corollarium filtrates reduced $S$. marinoi abundances by 24 and $47 \%$, respectively, and $S$. hangoei by 59 and $98 \%$.

At the end, $\mathrm{pH}$ was 8.19 (range: 8.02 to 8.36 ) in the control, 8.10 (8.04 to 8.22 ) in the $100 \%$ filtrates, and 8.27 in the Biecheleria baltica live cells treatment.

\section{Reciprocal effects of dinoflagellates}

The effects of dinoflagellate filtrates on the cell numbers of other dinoflagellate species were mostly positive (Fig. 4): Biecheleria baltica and Scrippsiella hangoei filtrates significantly increased the cell numbers of Gymnodinium corollarium (Tukey HSD, p = 0.034 and $\mathrm{p}=0.02$, respectively), and G. corollarium filtrate increased both $B$. baltica $(\mathrm{p}<0.001)$ and $S$. hangoei $(\mathrm{p}=0.003)$. The only significant positive effects on target fluorescence were caused by $G$. corollarium filtrate on $B$. baltica $(\mathrm{p}<0.001)$ and $S$. hangoei $(\mathrm{p}=0.019)$.

On the other hand, co-culturing with live dinoflagellate cells tended to inhibit the growth of other 
Donor: Biecheleria baltica

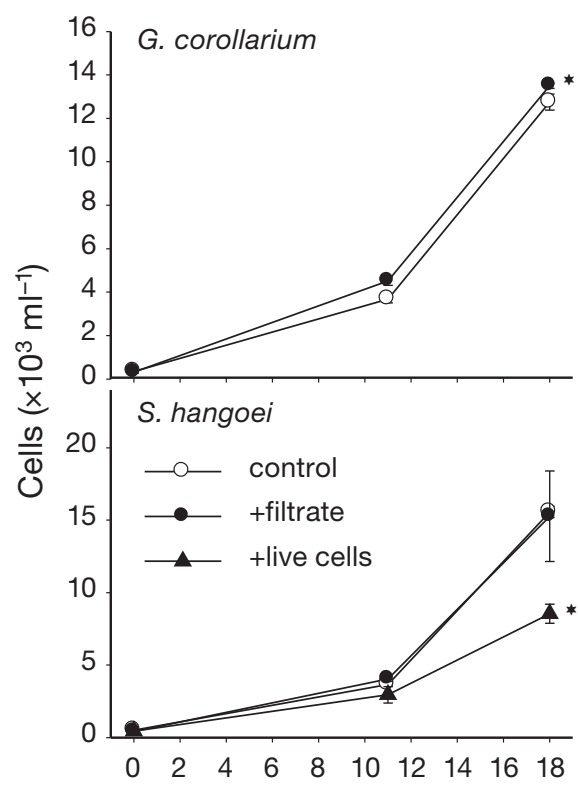

Donor: Gymnodinium corollarium

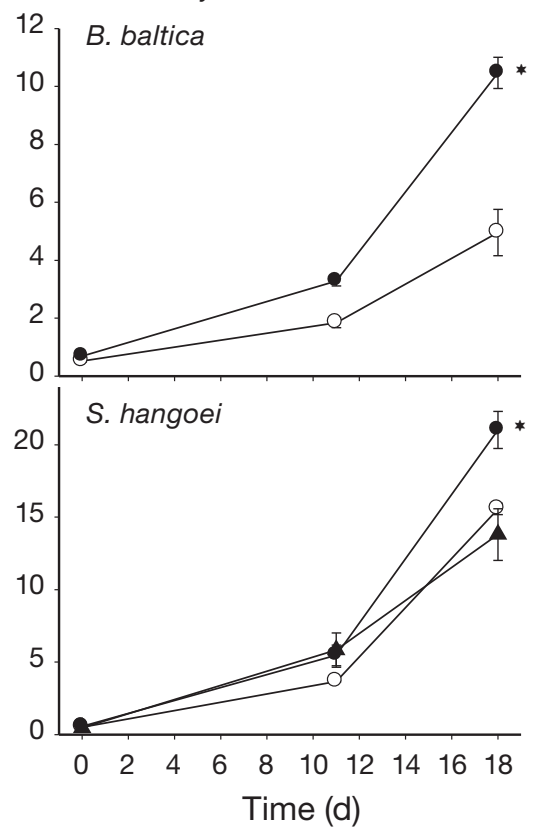

Donor: Scrippsiella hangoei
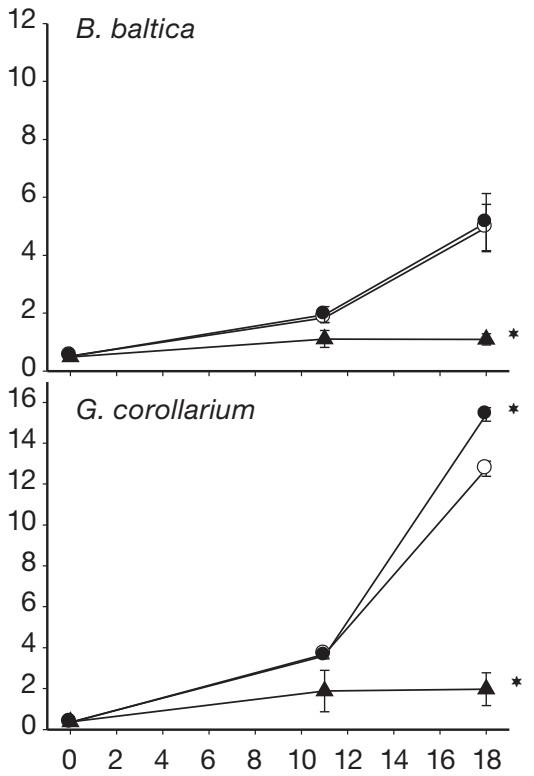

Fig. 4. Biecheleria baltica, Gymnodinium corollarium and Scrippsiella hangoei. Cell numbers ( $\mathrm{n}=3$, mean \pm SD) of the dinoflagellates exposed to control medium, as well as cell-free filtrates and live cells of the other dinoflagellates - left: $B$. baltica, middle: G. corollarium and right: $S$. hangoei. For B. baltica and G. corollarium, data from filtrate treatment vs. control only are presented. Treatments in which the cell numbers significantly differ from the control $(p<0.05)$ are marked with an asterisk

dinoflagellate species: presence of Biecheleria baltica cells significantly decreased cell numbers of Scrippsiella hangoei $(\mathrm{p}=0.002)$, and $S$. hangoei cells inhibited both B. baltica ( $\mathrm{p}<0.001$ ) and Gymnodinium corollarium ( $\mathrm{p}<0.001)$. Data on the reciprocal live cell effects of $B$. baltica and $G$. corollarium are not presented because these species could not be identified with certainty in mixed cultures.

On the last day, pH was on average 8.66 in the control, 8.78 in the filtrate treatments and 8.84 in the live cell treatments (Table 1).

\section{DISCUSSION}

Allelopathy is considered widespread among phytoplankton, especially in harmful algal bloom forming species that are also toxic to other aquatic organisms. However, toxicity and allelopathy are usually mediated by different compounds, e.g. in the harmful marine dinoflagellate genera Alexandrium, Karenia and Prorocentrum (Arzul et al. 1999, Sugg \& VanDolah 1999, Kubanek et al. 2005). Extracellular substances with haemolytic effects have been found to act as allelochemicals in some dinoflagellates (Rengefors \& Legrand 2001, Tillmann \& John 2002, Yamasaki et al. 2011b). The present study is the first report on allelopathic effects of the brackish-water dinoflagellates Biecheleria baltica, Gymnodinium corollarium and Scrippsiella hangoei on co-occurring diatoms. These species form spring blooms that are dense enough to be regarded as red tides, although they have not been found harmful in previous studies, i.e. they do not produce any known toxins. In a preliminary study, however, haemolytic activity was observed in S. hangoei (S. Suikkanen \& A. Kremp unpubl.), indicating that the species is potentially harmful to other aquatic organisms. This species has a genetically nearly identical sibling in Scandinavian freshwater habitats, Peridinium aciculiferum, which is known to be allelopathic (Rengefors \& Legrand 2001, Logares et al. 2007).

In the present study, allelopathic effects were mostly visible after 4 to $7 \mathrm{~d}$ (based on the fluorescence data with a sampling interval of 1 to $2 \mathrm{~d}$ ). This indicates that the effects were not primarily caused by haemolytic substances because cell lysis of target cells typically occurs within minutes to hours after exposure (Tillmann et al. 2008, Tang \& Gobler 2010, Chang 2011). Since rapid cell lysis was not observed in our target species, it seems that the allelopathic effects of these dinoflagellates are mediated by less acute mechanisms, e.g. by lowering the photosynthetic efficiency and causing a delayed growth re- 
sponse. Also, in some cases the dinoflagellate filtrates caused significant negative effects on target cell fluorescence, but not on cell numbers, indicating that the allelochemicals affected cell physiology, without reducing cell numbers. Also exudates of $\mathrm{Ka}$ renia brevis have been found to lower photosynthetic efficiency and increase membrane permeability of competing phytoplankton (Prince et al. 2008). Allelochemicals have been characterized for only a few dinoflagellate species: karlotoxins in Karlodinium veneficum (Adolf et al. 2006), amphipathic lytic compounds in Alexandrium tamarense (Ma et al. 2009) and unstable, polar organic molecules in $K$. brevis (Prince et al. 2010). All of these substances cause effects in $<48 \mathrm{~h}$, so different active principles are probably involved in the allelopathic effects of the species examined in the present study.

The allelopathic effects were species-specific, i.e. depending on both the donor and the target species. Gymnodinium corollarium negatively affected 5, Scrippsiella hangoei 4, and Biecheleria baltica 3 of the 5 target diatoms. Also, the diatoms differed in their response to the dinoflagellate treatments. Melosira arctica, Skeletonema marinoi and Thalassiosira baltica were inhibited by all 3 dinoflagellates. Diatoma tenuis was inhibited by 2 dinoflagellates (G. corollarium and cells of $S$. hangoei), and stimulated by 2 (filtrates of $B$. baltica and $S$. hangoei), whereas Chaetoceros cf. wighamii was inhibited by 1 (G. corollarium) and stimulated by 1 (S. hangoei). Speciesspecific consequences of allelopathy, also reported for e.g. Karenia brevis (Kubanek et al. 2005) and Alexandrium spp. (Tillmann et al. 2008), could be due to either differences in sensitivity of the target species or nature of the allelochemicals. The target diatoms may be differently susceptible to the same compounds, e.g. due to differences in their growth stage or cell concentration, while each dinoflagellate may produce a cocktail of allelochemicals, some of which inhibit multiple competitors and others that are allelopathic only towards certain species (Poulson et al. 2010). To ensure a competitive advantage in a natural assemblage with multiple competitor species, it is probably beneficial to produce multiple allelochemicals.

It is rather surprising that we found such clear negative effects of vernal dinoflagellates on co-occurring diatoms, which could be assumed to have adapted to the compounds produced by the sympatric dinoflagellates. It is possible that diatoms are generally more sensitive to allelochemicals produced by dinoflagellates than other groups of phytoplankton, or that the allelochemicals of these dinoflagellates are especially targeted against diatoms. Diatoms have been widely used as target species in allelopathy studies, and especially the globally occurring Skeletonema spp., Chaetoceros spp. and Thalassiosira spp. seem to be sensitive to allelochemicals excreted by various dinoflagellates (e.g. Gentien \& Arzul 1990, Arzul et al. 1999, Kubanek et al. 2005, Tillmann et al. 2007, 2009, Tameishi et al. 2009). On the other hand, diatoms may also produce allelochemicals (Yamasaki et al. 2011a), and in fact filtrates of some Baltic diatoms, used as targets in the present study, have been found to decrease the growth rates of some common vernal dinoflagellates, including Biecheleria baltica and Scrippsiella hangoei (Spilling 2008).

In contrast to diatoms, cell numbers of the cryptophyte Rhodomonas sp. were significantly increased by all 3 dinoflagellate species. In several studies, cryptophytes (together with diatoms) have been found most sensitive to allelochemicals produced by other phytoplankton, including dinoflagellates (e.g. Rengefors \& Legrand 2007, Tillmann et al. 2007, Tang \& Gobler 2010), and are therefore commonly used as test organisms to study mechanisms of allelopathy (Ma et al. 2009, Tillmann et al. 2009). On the other hand, filtrates and live cells of Karenia brevis also enhanced the growth of Rhodomonas lens, either as a result of stimulatory substances produced by $K$. brevis or a better ability of the cryptophyte to use nutrients in the form released by the dinoflagellate than in F/2 form when grown alone (Kubanek et al. 2005). Also in the present study, Rhodomonas sp. probably benefited from either organic matter released by the dinoflagellates or slightly higher nutrient concentrations in the dinoflagellate treatments compared with the control, whereas the lack of negative effects may again indicate that the allelochemicals produced by the Baltic vernal dinoflagellates have evolved to target specific competitors other than cryptophytes, e.g. diatoms.

As in the present study, co-culturing of donor and target species usually results in stronger allelopathic effects than the application of cell-free filtrate of the donor to the target (Tillmann \& John 2002, Kubanek et al. 2005, Tang \& Gobler 2010). In mixed cultures, allelopathic compounds are likely to be continually produced and released by live cells, and may even increase in concentration as the donor population density increases, whereas filtration may lead to the loss of some allelochemicals, and the substances that are left in the filtrates may decompose over periods of days to weeks (Kubanek et al. 2005). Other explanations for stronger inhibition of live cells compared to filtrates include the possible importance of cell-cell 
contact (Uchida et al. 1995, 1999), or the induction of allelopathy only in the presence of competitors (Kubanek et al. 2005).

In mixed culture experiments, potentially harmful effects due to high $\mathrm{pH}$ must be taken into account because a pH exceeding 9 to 9.5 can affect the growth and survival of marine phytoplankton (Goldman et al. 1981, Hansen 2002). Such a high pH can evolve in a non-aerated batch culture with a dense phytoplankton population. In the present study, $\mathrm{pH}$ was elevated up to almost 10 in the Chaetoceros cf. wighamii cultures treated with Biecheleria baltica (filtrate treatment 9.94, live cells treatment 9.75). However, this high $\mathrm{pH}$ had no significant effect on the growth of C. cf. wighamii compared with the control, in which the $\mathrm{pH}$ also increased to 9.92. The high $\mathrm{pH}$ was probably due to the extremely high cell densities of $C$. cf. wighamii (up to $500 \times 10^{3} \mathrm{cells} \mathrm{ml}^{-1}$ ). The only negative effect on $C$. cf wighamii was caused by live cells of Gymnodinium corollarium; however, high $\mathrm{pH}$ was an unlikely cause, because $\mathrm{pH}$ in the G. corollarium live cells treatment was even slightly lower (8.95) than in the control (9.05). In other donor-target combinations with significant negative effects, the $\mathrm{pH}$ either did not increase over 8.5, or the increase was even higher in the control, indicating that the negative effects of the treatments were not due to higher $\mathrm{pH}$. The only exceptions were the treatments with live Scrippsiella hangoei cells, where significantly lower target cell numbers coincided with a higher $\mathrm{pH}$ (up to 9.62) compared with the control. Nevertheless, negative effects of $S$. hangoei cells with high $\mathrm{pH}$ were not consistent: $C$. cf. wighamii was even stimulated in co-culture with $S$. hangoei in $\mathrm{pH}$ 9.75. It is possible that this species generally tolerates a higher $\mathrm{pH}$ than the other species examined. A pH tolerance of up to 9 was reported for growth of Chaetoceros didymus (Hansen 2002).

In our first set of experiments, focusing on the effects of dinoflagellates on a variety of target organisms, bloom concentrations of dinoflagellate cells were applied. The treatments were prepared from dinoflagellate cultures that were in late exponential or early stationary growth phase because many dinoflagellate species, including the closely related Peridinium aciculiferum, have been found to be most allelopathic in stationary growth phase (Kayser 1979, Arzul et al. 1999, Rengefors \& Legrand 2001). Thus, the results may relate mostly to established dinoflagellate blooms, which is why another experiment was conducted to examine the lowest effective cell concentration that produced significant allelopathic effects on one of the most sensitive target species,
Skeletonema marinoi. The lowest cell concentrations that (as filtrates) significantly reduced $S$. marinoi cell numbers were 10100 Biecheleria baltica cells ml ${ }^{-1}$ (based on the first experiment; Fig. 2), 8100 Gymnodinium corollarium cells $\mathrm{ml}^{-1}$ and 5800 Scrippsiella hangoei cells $\mathrm{ml}^{-1}$. Fluorescence of $S$. marinoi was already suppressed by filtrate from $1200 \mathrm{~S}$. hangoei cells $\mathrm{ml}^{-1}$. Other studies have reported effective cell concentrations for dinoflagellate filtrates ranging from as low as 100 Alexandrium tamarense cells ml ${ }^{-1}$ (Arzul et al. 1999) up to several thousands of Karenia brevis cells ml ${ }^{-1}$ (Kubanek et al. 2005). In the present study, $S$. hangoei filtrate had the strongest allelopathic effects on $S$. marinoi, which was reduced by ca. $98 \%$ at the highest $S$. hangoei cell concentration examined: 12000 cells ml$^{-1}$. In contrast, the highest concentrations of the other dinoflagellates, $26000 \mathrm{~B}$. baltica and 16000 G. corollarium cells ml ${ }^{-1}$, only caused 32 and $47 \%$ reductions in $S$. marinoi cell numbers, respectively. Only live $B$. baltica cells $\left(26000\right.$ cells ml$^{-1}$ ) caused a $95 \%$ reduction in $S$. marinoi cells, comparable to that of the strongest $S$. hangoei filtrate. It is probable that the effects of live dinoflagellate cells are already visible at lower concentrations than those of filtrates, since live cells tend to exert stronger negative effects on targets than filtrates, as discussed earlier in the 'Discussion' (previous page).

Filtrates of Biecheleria baltica, Gymnodinium corollarium and Scrippsiella hangoei either stimulated (in 4 out of 6 donor-target combinations) or had no effect on the growth of the other dinoflagellate species, but in mixed cultures the target species were either suppressed (in 3 out of 4 cases) or unaffected. This indicates that the allelochemicals produced by these dinoflagellates are not primarily targeted against the other sympatric dinoflagellate species, but the filtrates rather contain some organic material originating from the dinoflagellate cells that is directly useful for the other dinoflagellates. The beneficial effect was stronger than the possibly negative effect caused by allelochemicals. Growth of 2 species in mixed batch cultures often depends strongly on the ratio between cell numbers of the species inoculated at the start of the experiment, so that the species inoculated at a higher concentration usually prevails and suppresses the competitor. The suppression occurs mainly by nutrient competition in exponential stage, but at maximum cell densities an additional effect of inhibiting metabolic products can be involved (Kayser 1979). In the present study, we tried to avoid the effects of nutrient competition by regular inorganic nutrient additions to the mixed cultures, and thus the negative effects observed were probably due to some 
other mechanism, e.g. competitor-induced allelopathy or inhibition through direct cell contact (Uchida et al. 1995, 1999).

\section{CONCLUSIONS}

The Baltic vernal dinoflagellates Biecheleria baltica, Gymnodinium corollarium and Scrippsiella hangoei have allelopathic effects that seem to be specifically targeted against co-occurring diatoms. The effects are both donor and target speciesspecific, so that some of the most important vernal diatom species such as Skeletonema marinoi, Thalassiosira baltica and Melosira arctica are severely inhibited, whereas some other species belonging to the same community, such as Chaetoceros cf. wighamii and Diatoma tenuis are less affected. The dinoflagellates may also suppress the growth of the other sympatric dinoflagellate species, but they seem to have no negative effects on the co-occurring cryptophyte Rhodomonas sp. The effects are probably not mediated by lytic compounds, but rather through an unknown mechanism, causing reductions in growth rate on a time scale of several days. The negative effects of $S$. hangoei may include elevation of $\mathrm{pH}$ to levels intolerable by certain phytoplankton species.

Collectively, these results indicate that dinoflagellates may use allelopathy to compensate for their lower growth rates compared to diatoms, although further studies are needed to elucidate the role of dinoflagellate allelochemicals in the natural spring phytoplankton community. However, the allelopathic effects are probably important only after the development and concentration of an adequate number of dinoflagellate cells in the surface layer (Maestrini \& Bonin 1981, Jonsson et al. 2009), either under ice (Spilling 2007), or as a result of hydrographic conditions in early spring that favor dinoflagellates over diatoms, e.g. early stratification of the water column (Wasmund et al. 1998). In the northern Baltic Sea dinoflagellate blooms are typically initiated by such conditions. Stratification, e.g. under the ice, may lead to the build-up of a sizeable inoculum population well before the break-up of the ice cover and the rise of the spring bloom diatoms. Allelopathic substances released by such a dinoflagellate population immediately when conditions allow potentially competing diatoms to grow should be efficient enough to contribute to their suppression and the maintenance of dinoflagellate dominance, even if the effects are not immediate but manifest at a scale of days. On the con- trary, diatoms grow rapidly in other years when the water column is initially more turbulent and gain dominance over dinoflagellates, possibly also producing chemicals that inhibit dinoflagellate growth.

Acknowledgements. This work was supported by grants from the Academy of Finland (S.S., K.S., A.K.; grant 111336) and Walter \& Andrée de Nottbeck Foundation (P.H.).

\section{LITERATURE CITED}

Adolf JE, Bachvaroff TR, Krupatkina DN, Nonogaki H and others (2006) Species specificity and potential roles of Karlodinium micrum toxin. Afr J Mar Sci 28:415-419

Arzul G, Seguel M, Guzman L, Erard-Le Denn E (1999) Comparison of allelopathic properties in 3 toxic Alexandrium species. J Exp Mar Biol Ecol 232:285-295

Chang FH (2011) Toxic effects of three closely-related dinoflagellates, Karenia concordia, K. brevisulcata and K. mikimotoi (Gymnodiniales, Dinophyceae) on other microalgal species. Harmful Algae 10:181-187

Gentien P, Arzul G (1990) Exotoxin production by Gyrodinium cf. aureolum (Dinophyceae). J Mar Biol Assoc UK 70:571-581

Goldman JC, Dennett MR, Riley CB (1981) Test for allelopathic interactions between two marine microalgal species grown in intensive cultures. Curr Microbiol 6:275-279

Guillard RL (1975) Culture of phytoplankton for feeding marine invertebrates. In: Smith WL, Chanley MH (eds) Culture of marine invertebrate animals. Plenum Press, New York, NY, p 29-60

Hällfors G (2004) Checklist of Baltic Sea phytoplankton species (including some heterotrophic protistan groups). Balt Sea Environ Proc 95, Helsinki Commission, Helsinki

Hansen PJ (2002) Effect of high pH on the growth and survival of marine phytoplankton: implications for species succession. Aquat Microb Ecol 28:279-288

Heiskanen AS (1993) Mass encystment and sinking of dinoflagellates during a spring bloom. Mar Biol 116:161-167

Jaanus A, Hajdu S, Kaitala S, Andersson A and others (2006) Distribution patterns of isomorphic cold-water dinoflagellates (Scrippsiella/Woloszynskia complex) causing 'red tides' in the Baltic Sea. Hydrobiologia 554:137-146

Jonsson PR, Pavia H, Toth G (2009) Formation of harmful algal blooms cannot be explained by allelopathic interactions. Proc Natl Acad Sci USA 106:11177-11182

Kayser H (1979) Growth interactions between marine dinoflagellates in multispecies culture experiments. Mar Biol 52:357-369

Klais R, Tamminen T, Kremp A, Spilling K, Olli K (2011) Decadal-scale changes of dinoflagellates and diatoms in the anomalous Baltic Sea spring bloom. PLoS ONE 6(6):e21567

Kremp A, Heiskanen AS (1999) Sexuality and cyst formation of the spring bloom dinoflagellate Scrippsiella hangoei in the coastal northern Baltic Sea. Mar Biol 134:771-777

Kremp A, Elbrächter M, Schweikert M, Wolny JL, Gottschling M (2005) Woloszynskia halophila (Biecheler) comb. nov.: a bloom-forming cold-water dinoflagellate cooccurring with Scrippsiella hangoei (Dinophyceae) in the Baltic Sea. J Phycol 41:629-642

Kremp A, Tamminen T, Spilling K (2008) Dinoflagellate bloom formation in natural assemblages with diatoms: 
nutrient competition and growth strategies in Baltic spring phytoplankton. Aquat Microb Ecol 50:181-196

Kremp A, Rengefors K, Montresor M (2009) Species-specific encystment patterns in three Baltic cold-water dinoflagellates: the role of multiple cues in resting cyst formation. Limnol Oceanogr 54:1125-1138

Kubanek J, Hicks MK, Naar J, Villareal T (2005) Does the red tide dinoflagellate Karenia brevis use allelopathy to outcompete other phytoplankton? Limnol Oceanogr 50: 883-895

Larsen J, Kuosa H, Ikävalko J, Kivi K, Hällfors S (1995) A redescription of Scrippsiella hangoei (Schiller) comb. nov. - a 'red tide' dinoflagellate from the northern Baltic. Phycologia 34:135-144

> Logares R, Rengefors K, Kremp A, Shalchian-Tabrizi K and others (2007) Phenotypically different microalgal morphospecies with identical ribosomal DNA: a case of rapid adaptive evolution? Microb Ecol 53:549-561

Ma H, Krock B, Tillmann U, Cembella A (2009) Preliminary characterization of extracellular allelochemicals of the toxic marine dinoflagellate Alexandrium tamarense using a Rhodomonas salina bioassay. Mar Drugs 7:497-522

Maestrini SY, Bonin DJ (1981) Allelopathic relationships between phytoplankton species. Can Bull Fish Aquat Sci 210:323-338

> Moestrup Ø, Lindberg K, Daugbjerg N (2009) Studies on woloszynskioid dinoflagellates IV: the genus Biecheleria gen. nov. Phycol Res 57:203-220

Niemi $\AA$ (1975) Ecology of phytoplankton in the Tvärminne area, SW coast of Finland. II. Primary production and environmental conditions in the archipelago and the sea zone. Acta Bot Fenn 105:1-73

> Poulson KL, Sieg RD, Prince EK, Kubanek J (2010) Allelopathic compounds of a red tide dinoflagellate have species-specific and context-dependent impacts on phytoplankton. Mar Ecol Prog Ser 416:69-78

> Prince EK, Myers TL, Kubanek J (2008) Effects of harmful algal blooms on competitors: allelopathic mechanisms of the red tide dinoflagellate Karenia brevis. Limnol Oceanogr 53:531-541

> Prince EK, Poulson KL, Myers TL, Sieg RD, Kubanek J (2010) Characterization of allelopathic compounds from the red tide dinoflagellate Karenia brevis. Harmful Algae 10: $39-48$

Rahm L, Conley D, Sandén P, Wulff F, Stålnacke P (1996) Time series analysis of nutrient inputs to the Baltic Sea and changing DSi:DIN ratios. Mar Ecol Prog Ser 130: 221-228

Rengefors K, Legrand C (2001) Toxicity in Peridinium aciculiferum - an adaptive strategy to outcompete other winter phytoplankton? Limnol Oceanogr 46:1990-1997

Rengefors K, Legrand C (2007) Broad allelopathic activity in Peridinium aciculiferum (Dinophyceae). Eur J Phycol 42: 341-349

Smayda TJ (1997) Harmful algal blooms: their ecophysiology and general relevance to phytoplankton blooms in the sea. Limnol Oceanogr 42:1137-1153

Spilling K (2007) Dense sub-ice bloom of dinoflagellates in the Baltic Sea, potentially limited by high $\mathrm{pH}$. J Plankton Res 29:895-901

Spilling K (2008) Diatom effect on dinoflagellate growth. In: Moestrup Ø, Doucette G, Enevoldsen H, Godhe A and others (eds) Proc 12th Int Conf Harmful Algae, Copenhagen, Sep 4-8, 2006. International Society for the Study of Harmful Algae and Intergovernmental Oceanographic Commission of UNESCO, Copenhagen, p 9-12

Sugg LM, VanDolah FM (1999) No evidence for an allelopathic role of okadaic acid among ciguatera-associated dinoflagellates. J Phycol 35:93-103

Sundström AM, Kremp A, Daugbjerg N, Moestrup Ø, Ellegaard M, Hansen R, Hajdu S (2009) Gymnodinium corollarium sp. nov. (Dinophyceae) - a new cold-water dinoflagellate responsible for cyst sedimentation events in the Baltic Sea. J Phycol 45:938-952

Tameishi M, Yamasaki Y, Nagasoe S, Shimasaki Y, Oshima Y, Honjo T (2009) Allelopathic effects of the dinophyte Prorocentrum minimum on the growth of the bacillariophyte Skeletonema costatum. Harmful Algae 8:421-429

Tang YZ, Gobler CJ (2010) Allelopathic effects of Cochlodinium polykrikoides isolates and blooms from the estuaries of Long Island, New York, on co-occurring phytoplankton. Mar Ecol Prog Ser 406:19-31

Tillmann U, John U (2002) Toxic effects of Alexandrium spp. on heterotrophic dinoflagellates: an allelochemical defence mechanism independent of PSP-toxin content. Mar Ecol Prog Ser 230:47-58

Tillmann U, John U, Cembella A (2007) On the allelochemical potency of the marine dinoflagellate Alexandrium ostenfeldii against heterotrophic and autotrophic protists. J Plankton Res 29:527-543

Tillmann U, Alpermann T, John U, Cembella A (2008) Allelochemical interactions and short-term effects of the dinoflagellate Alexandrium on selected photoautotrophic and heterotrophic protists. Harmful Algae 7:52-64

- Tillmann U, Alpermann T, da Purificação RC, Krock B, Cembella A (2009) Intra-population clonal variability in allelochemical potency of the toxigenic dinoflagellate Alexandrium tamarense. Harmful Algae 8:759-769

> Uchida T, Yamaguchi M, Matsuyama Y, Honjo T (1995) The red tide dinoflagellate Heterocapsa sp. kills Gyrodinium instriatum by cell contact. Mar Ecol Prog Ser 118: 301-303

Uchida T, Toda S, Matsuyama Y, Yamaguchi M, Kotani Y, Honjo $T$ (1999) Interactions between the red tide dinoflagellates Heterocapsa circularisquama and Gymnodinium mikimotoi in laboratory culture. J Exp Mar Biol Ecol 241:285-299

Wasmund N, Uhlig S (2003) Phytoplankton trends in the Baltic Sea. ICES J Mar Sci 60:177-186

Wasmund N, Nausch G, Matthäus W (1998) Phytoplankton spring blooms in the southern Baltic Sea - spatio-temporal development and long-term trends. J Plankton Res 20:1099-1117

> Windust AJ, Wright JLC, McLachlan JL (1996) The effects of the diarrhetic shellfish poisoning toxins, okadaic acid and dinophysistoxin-1, on the growth of microalgae. Mar Biol 126:19-25

Wu JT, Kuo-Huang LL, Lee J (1998) Algicidal effect of Peridinium bipes on Microcystis aeruginosa. Curr Microbiol 37:257-261

Yamasaki Y, Ohmichi Y, Shikata T, Hirose M, Shimasaki Y, Oshima Y, Honjo T (2011a) Species-specific allelopathic effects of the diatom Skeletonema costatum. Thalassas 27:21-32

> Yamasaki Y, Zou Y, Go J, Shikata T and others (2011b) Cell contact-dependent lethal effect of the dinoflagellate Heterocapsa circularisquama on phytoplankton-phytoplankton interactions. J Sea Res 65:76-83 